\title{
What Can't Be Said Can Be Written: The Representation of Silence in Herta Müller's Visual Texts Amal Hamza Shenishen
}

(Lecturer, Department of English, College of Arts, Tanta University)

\section{ABSTRACT}

What is going on? How can silence be said, and be a source of meaning? Silence is defined as a complete absence of sound, an absence of information, or even a temporal limitation of speech. Silence is not a failure of language to communicate. When people get short of words, feelings, safe space, or even want to flee from punishment, they choose to keep silent. Yet, silence could be a smart tactic to cross borders, to personify agony, and to engage others' imagination. Silence can open up new contexts and reveal hidden feelings in an unprecedented manner. The oeuvre of the Romanian writer Herta Müller exemplifies the absence of sound and even the absence of life itself. Müller manages to break through the formal constraints of language in a significant and artistic manner. She has a peculiar and creative way of describing her world. Her creativity is not limited to language as she always questions the power of language to express thoughts and feelings. Language could be a space where Müller can bend words, forms, colors, and shapes. In her collage poetry, Müller can defamiliarize language in an unconventional manner. She uses a unique art form, the art of cut-ups that makes the words and images speak for themselves. Faced with physical threat and psychological repression of the oppressive and dictatorial regime of Nicolae Ceausescu, Müller resorted to silence to say what can't be said.

This paper aims at highlighting the art of collage as a tool used by Herta Müller to express silently incongruent images and texts to express fear and oppression. It will scrutinize the authenticity of the collage poetry of Herta Müller and how her rich and colorful images helped her to gain a foothold in the new setting. It also attempts to elucidate the difference between the silence of language and the silence of things.

KEYWORDS: Collage Poetry- Herta Müller - Hannah Ardent - SilenceSpace- Metaphoric Language.

العدد السادس والعشرون (الجزء الرابع) • r. r. 
What Can't Be Said Can Be Written: The Representation of Silence in Herta Müller's Visual Texts

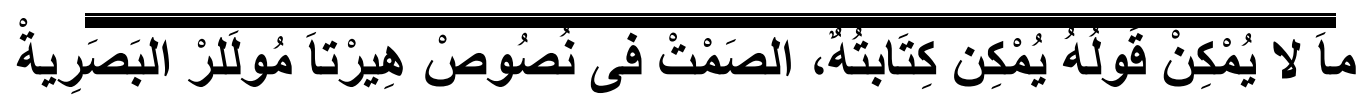 أمل حمزة شنيشن}

(مدرس بقسم اللغة الإنجليزية- كلية الأداب- جامعة طنطا)

مالذي يجري؟ كيف يُقال أن الصمت مصدر للمعاني؟ الصمت هو الغياب التام للصوت، أو غياب المعلومات، أو حتى الحد الزمني للحديث. الصمت ليس فنثل التواصل. عندما

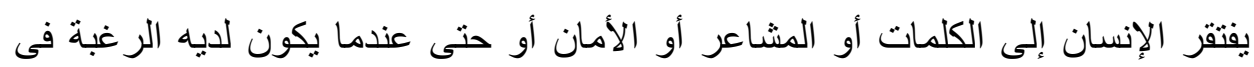

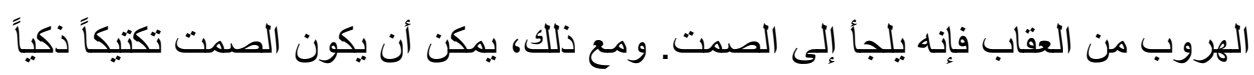
للعبور عبر الحدود وتجسيد الألم. يمكن للصمت أن يفتح سِياقات جديدة ويكثف عن مشاعر خفية بطريقة غير مسبوقة. تُجسد أعمال الكاتبة الرومانية هيرتا موللر غياب الصوت بل وغياب الحياة. تمكنت موللر من اختراق القيود الرسمية للغة بطريقة فنية

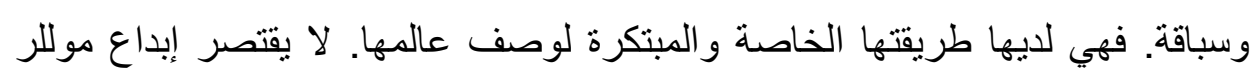
على اللغة لأنها ثُشكلك فى قدرة اللغة فى التعبير عن الأفكار و المشاعر. تستخدم موللر فناً فريداً وهو فن القطع التى تجعل الكلمات والصور تتحدث عن نفسها. فى مواجهة التهديد الجسدي والقمع النفسي للايكتاتور نيكولاي تشاوشيسكو، لجأت موللر إلى هونى الصمت لتقول من خلاله ما لا تستطيع البوح به. تهدف هذه الورقة البحثية إلى إبراز فن

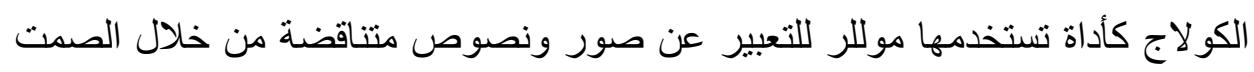
وذلك للتعبير عن الخوف و القمع الذى تعاني منه.

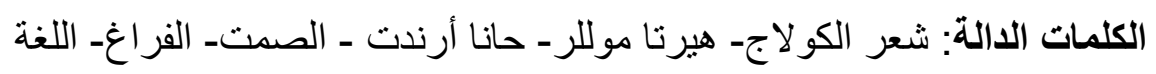
المجازية 


\section{What Can't Be Said Can Be Written: The Representation of Silence in Herta Müller's Visual Texts Amal Hamza Shenishen}

(Lecturer, Department of English, College of Arts, Tanta University)

\section{1- INTRODUCTION}

The German Nobel Prize laureate Herta Müller, who was born in the Romanian Banat-Swabian village, transposes in her writings the horrors she has experienced in the ethnic German community and then under the communist rule of Nicolae Ceausescu (1965-1989). She lived for over thirty years in oppression and injuries. Müller didn't choose the themes of her writings; the themes of fear, oppression, and silence chose her. Müller resisted political repression, lack of freedom, the humiliation of the individual, and the totalitarian power through her images and a marked use of language. Müller's enforced silence, as well as the fragmented language and gaps of her collages, are meant to say what cannot be said. She said in her Nobel acceptance speech: "What can't be said can be written, because writing is a silent act, a labor from the head to the hand" (7). But how can we read and appreciate what is not said? How can we capture the effect of Müller's poetics if what is not said depends on Müller's mistrust of language, and shifts the responsibility of interpretation to the reader?

Significantly, Müller is exclusively known as a novelist since none of her poetry or collages has yet been translated into English. Yet, the art of collage is Müller's favored genre and is central to her output. She tries to present her injuries and painful past through an interaction between the visual image and the verbal text. Fragmentation and gaps as presented in the collages reflect the fragmented life of Müller. Herta Müller is privileged in presenting the un-representable through the creation of a world of collages. Her life and her writings are a complicated collage, and she is a collage herself. Müller lived in Romania, and her output belongs to the

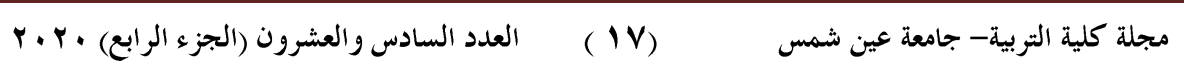


What Can't Be Said Can Be Written: The Representation of Silence in

Herta Müller's Visual Texts

Romanian literature but she never claimed to be Romanian. Although she was deported by authorities from communist Romania to West Germany in 1987, Müller was not considered a refugee or even a migrant writer. Müller was regarded as an outsider in both Romania and Germany. Germany for here is not a Heimat /homeland, but rather a different location. She was awarded the Nobel Prize in literature only because of writing about dictatorship rather than literature. Like a collage that reflects multiple interpretations, Müller's life goes in different directions, and probes into the meaning of the unspeakable. Being a collagist, Müller has found a way to express silently her discomfort, anger, and fear through a process of deconstruction and reconstruction. She first cuts images and words from different print sources with a merciless scissor to create messiness and alienation similar to her life. Then, she goes on a time-consuming process of electing and pasting unrelated words in different shapes, fonts, and colors to create a pleasant and colorful whole that cannot conceal its fragmented reality. Fragmentation as a form of destruction is present in both the process of cutting and pasting. Silence which is not a thing, but rather an absence of something, helps to bring forth more abstract meanings and expressions through codifying both the form and content of fragmentation. Müller is quite aware of the relationship between image and word that expresses the fragmentation of the psyche, and her tactics unfold a novel and an aesthetic approach.

Far from Müller's fragmented language and oppressed memories, she knows well how to handle her inherited fear and how to overcome her disintegrated self through moving into a silent medium of collage making. It's not a contradiction to say that Müller prefers to talk in silence. Silence is as necessary as speech. It hides the unspeakable terror, expresses anger, works as a relief and support, and is considered a tactic of survival. From childhood, Müller lived in silence, and practiced different types of silences. She says: "I have packed myself into silence so deeply and for so

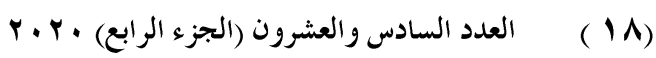

مجلة كلية التربية- جامعة عين شمس 


\section{Amal Hamza Shenishen}

long that I can never unpack myself using words. When I speak, I only pack myself a little differently" (Hunger Angel 2). Philosophically, collage is associated with the concept of randomness, of traumatic experience that cannot be assimilated, and of things that cannot be told explicitly. Because words alone cannot express the haunting memories and feelings, Müller resorts to a coalition of pictorial and verbal collages as an art of resistance against dictatorships.

This analytical paper is driven by the following research questions: What is collage? What is silence? Can readers able to interpret Müller's collages as a visual art without being acquainted with her suffering? Can language affect people physically?

\section{2- THE THEORITICAL PERSPECTIVE}

This paper scrutinizes Müller's collage poems in light of Hannah Arendt's political thought to build a more constructive interpretation of the collages. Hannah Arendt (1906-75) is one of the widely seminal American philosophers who gained renewed credibility after the fall of communism in 1989. Arendt's writings cover a wide range of topics specifically about power and terror as being the essence of the totalitarian and the dictatorial discourse. She was striving hard to grasp the calamitous effects of both Nazism and Stalinism; the twin horrors of the $20^{\text {th }}$ century. Arendt's books investigate the conditions of humanity in dark times. Books as The Origins of Totalitarianism (1951), Ideology and Terror: A Novel Form of Government (1953), The Human Condition (1958), Men in Dark Times (1968), On Violence (1970), and her last and unfinished work The Life of the Mind (1977 \&1978), arise from personal concerns, yet they are grounded in a critique of systematic moral philosophy.

Hannah Arendt was committed to tell the truth; to speak her mind without being afraid. Her primary goal is in highlighting the humanistic voice, in placing the self at the center, and in creating meaning for one's life. Like Arendt, Müller can be best described as

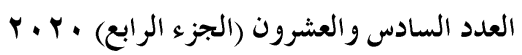

(19)

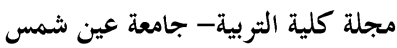


a political writer, but her impetus has always been personal. Her hand-made collage poems are mainly concerned with violence, displacement, destructiveness, and trauma of her daily life in her small village in Romania and later in Germany. Müller's pregnant collage poems are a conceptualization of physical, emotional, and intellectual violence, and terror.

\section{3- THE ART OF COLLAGE}

A collage is a visual or/and verbal representation of condensed and fragmented materials with different shapes, forms, and colors that serves different purposes. Collages help in presenting issues hard to be presented in a typical way. The art of collage involves both a creative process from the side of the collagist and an analytical process from the side of the reader. David Hockney differentiates between two kinds of collages; the manipulative collage and the honest collage:

Your eye takes in the whole [flat] surface instantly. The eye can't do that in collage, because the collage entails another time existing there. When people make deceitful collage...they try to make it look as if it's all the same time. Honest collage deliberately puts another time there, so that the eye will sense these two different times and therefore space. (163)

In her Nobel acceptance speech, Müller does not go so far away, she asserts: "In writing, it is not a matter of trusting, but rather of the honesty of the deceit" (8). Müller's practice of collage is closely intertwined with her idea that language can be understood in light of suffering and trauma. The art of collage is revolutionary; it enables the reader to see beyond words, to hear the unspeakable voices, and to uncover the hidden meanings. It depends on pre-existing material and works in transforming it into something new. Etymologically, the word collage is taken from the French "coller" which means to paste or to glue. The practice of collage was first initiated in the

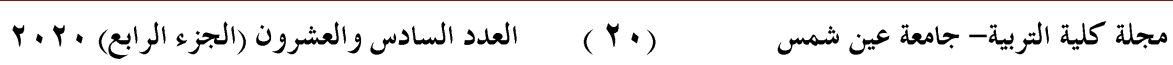




\section{Amal Hamza Shenishen}

1920s by the Cubists then challenged and developed by the Dadaists and Surrealists. The aesthetic aspect of collage or visual art lies in what is left unsaid. It is considered a manipulative art that demands the indirectness of both content and form. The atrocities of wars as well as the totalitarian and dictatorial regimes around the world have contributed largely to the development of the art of collage. Cutting and pasting words from different sources resemble a puzzle that needs rearranging its parts, and invites multiple readings to get all the possible meanings. Rosalind Krauss interprets collages as a metalanguage of the visual in the sense of a superimposition of grounds, each of which points to another and ultimately to an absent origin (37). This makes collage a kind of metaphor that has a visual play of signs that fits the twenty-first-century readers.

In 1987, Herta Müller has published her earliest volume of collage entitled Der kalte Schmuck des Lebens (The cold ornament of life). It includes funeral imagery where colors are muted to display her reality. In 1991, she wrote Der Teufel sitzt im Spiegel, (The devil is sitting in the mirror) that shows actual postcard-size collage. In the 2000s, Müller has published three German-language collage collections: Der Wächter nimmt seinen Kamm (The guard takes his comb) in 1993, Im Haarknoten wohnt eine Dame (A lady lives in a hair knot) in 2000, and Die Blassen Herren mit den Mokkatassen (The pale gentlemen with the mocha cups) in 2005. Müller has refined her art of collage where a cut-out image is creatively selected to meet a cut-out text. In 2005, Müller has published her first Romanian-language collage entitled "Est sau nu este Ion" (Is it or is not Ion).

Herta Müller is interested in language in a constructive, not a destructive way. For her, language can kill and heal at the same time. Thus, collage is simply the most succinct and appropriate art that enables Müller to make survival possible through silent resistance. She is resisting without appearing to do so simply because collaging allows camouflage. A collagist resembles a 
What Can't Be Said Can Be Written: The Representation of Silence in

Herta Müller's Visual Texts

gymnast who moves swiftly between words, colors, and images. Ultimately, Müller managed to make her readers hear voices and see images through penetrating deeply underneath the visual and verbal meanings. Lyn Marven considers Müller's collages an aesthetic of dissonance:

Müller's collages, simple as they are, share themes and structures with the prose texts, extending her representations of trauma into more literal forms. The collages develop the notion of fragmentation and foreground the kind of interaction between different levels of the work which derives from the dissolution of boundaries. Elements of the grotesque and the poetic devices in the texts mark a move away from the subjective effect of trauma to an external viewpoint and, as a result, the collages have taken on an aspect of playfulness. (Trauma, Fragmentation 410-11).

In general, the uniqueness of Müller's collages and her adoption of details as an art of resistance is a panorama that surpasses Dadaism and Surrealism. Müller's play with colors, fonts, and sizes is a currency of Dadaism, while fragmentation of bodily imagery was a tribute of Surrealism. Although Müller's collages are simple, and the text is easy to be accessed, her metaphoric language opens different interpretations. Müller's collages depend on the Cubist tactics of cutting and pasting, and their grid-like structure highlights the visual implications. The phonic aspect of words and the discrepancy of images of the collages justify Müller's interest in Surrealism. Müller's novel approach in highlighting the function of metaphoric language in her collages challenges scholars and critics alike. Her highly poetic language "defies linguistic and literary conventions" (Metaphoric Conceptualization 73). Throughout her collages, Müller surpasses her reader's expectation by liberating herself from conventional writing and focusing on the things that are left unsaid.

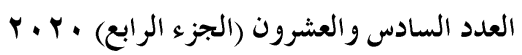

$(Y Y)$

مجلة كلية التربية- جامعة عين شمس 


\section{4- TACTICS OF COLLAGES}

A psychoanalyst once said, "no speech remains without an answer, even if is met with silence, provided there is a listener" (Lacan 247). Müller's collages speak differently, and her silent and fragmented language challenges her readers to speculate what is left unsaid. Müller's collages have been developed since she wrote Reisende auf einem Bein (Travelling on One Leg) where the protagonist Irene produces collages to express her fragmented psyche after emigrating from Romania to West Germany. A glimpse of Müller's collage poems reveals a unique art form where words and images are torn out from their context and are freed to speak the truth, to denote multiple meanings, and to defy fear. Müller has stated more than once that she does not trust language albeit she writes through language. So, what can Müller do in such a dilemma? She can create a magical space where the oppressive regime and the secret police are not allowed to log on. Although this space is mute and void, it is a powerful way to unmute Müller's long-silenced voice and to speak the unspeakable. This makes the reader entirely responsible for the embedded meaning. Each collage depends on the reproduction of a pre-existed text, cut out from different sources with highly politicized connotations. These words are not new, but rather words charged with new and hidden meanings that help to promote new connections without speaking explicitly.

Like Irene, Muller is fascinated by visual collages as a way to rearrange her reality. She uses Surrealist and Dadaist techniques that highlight the irrationality and randomness of modern life because of the horrors of wars. At first glance, Muller's collages are distinguished by two main and interrelated elements; multiple details charged with different meanings, and the aesthetic function of the text. Their visual quality and fragmented language pinpoint the silent sound, and what is left to the reader is to reassemble the

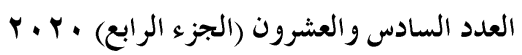

$(Y M)$

مجلة كلية التربية- جامعة عين شمس 
What Can't Be Said Can Be Written: The Representation of Silence in

Herta Müller's Visual Texts

fragmented pieces into a whole. So, the task of making sense of such a type of encoded collages lies mostly on the reader.

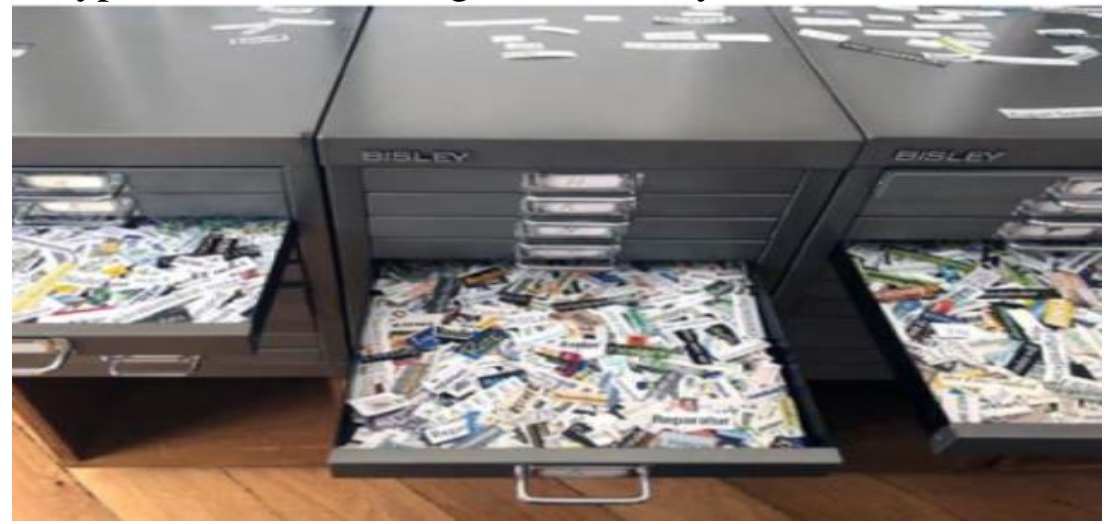

Photograph of Herta Müller's drawer

Herta Müller's first picture-based collages were initially approached as a game, and then she added texts with visual dimension. It comes as no surprise that the process of cutting and pasting these fragmented pieces releases a tremendous amount of energy and gives Müller a sense of pleasure. This pleasure comes from her ability to use the language of the oppressive regime as a way of resistance and survival. Surprisingly, Müller can speak in silence what cannot be expressed in speech. The dilemma is that; either to accept suffering or to resist without leaving a trace. According to Katrin Kohl, Müller relies on " the significance and power of language ... when language gives way to silence in response to a life-threatening situation" (28). Initially, Müller chose the career of writing as a way to overcome the many silences around her. Silence, then, has become the safe space through which she can speak the truth about her frustration and dissatisfaction with the social order. In her Nobel acceptance speech Müller says that she speaks voicelessly because she reacted to the fear of death with a thirst for life:

I talked a great deal during the dictatorship, mostly because I decided not to blow the trumpet. Usually, my talking led to 


\section{Amal Hamza Shenishen}

excruciating consequences. But the writing began in silence, there on the stairs, where I had to come to terms with more than could be said. What was happening could no longer be expressed in speech (7).

Müller likewise conjures silence to comprehend the communicative potential of inanimate entities as Pavlo Shopin argues. Shopin maintains that Müller is quite aware of the difference between keeping silent and the absence of sound:

Müller humanizes the world when she ascribes to its inanimate entities the ability to keep silent. Silence can also metonymically stand for the mental states of those keeping silent or for their complex social actions; it serves as a central reference point for trauma, fear, guilt, suffering, writing, and collaboration. In Müller's works, metaphor and metonymy can interact and contribute to the understanding of silence. The author consistently highlights the figurative meaning of silence by estranging the trope linguistically and conceptually. Silence refers to the absence and failure of (but also implies the potential for) language and communication; and its use as a trope brings to the fore the search for meaning, expression, and social interaction (The Trope of Silence 241).

To help expose the many silences around her, Müller started early to listen to the sound of objects, animals, and plants within her environment. For example, when she was asked to collaborate with the secret police, she refused saying: "I don't have the character for this". This answer has made the officer so angry that he hurled a vase against the wall. Müller, who is endowed with a of multisensory talent, has listened to the sound of the inanimate vase: "As it shattered it made a grinding sound, as though the air had teeth" (Every Word Knows Something 2).

To belong to the ethnic minority in the Banat-Swabian village, to suffer from fragmentation, hybridization of your cultural identity, to be isolated and treated as a traitor to the communist order, have 
negatively affected Herta Müller and shaped her unique tactics of writing. Even after immigrating to West Germany, Müller is still haunted by the memories of persecution and oppression of totalitarian Romania. She first knew dictatorship in her small village, and in Germany, she lived in "ein fremder Ort" (a strange place). So, Müller persisted to reflect her own traumatic experiences in collages as a way to voice the numerous silenced victims.

\section{5- MAJOR THEMES}

Herta Müller's collages arise from personal concerns, and from inside perspectives of her life that make her often revisit themes multiple times. Her collages can be described as being porous, ungraspable, and familiar at the same time, with local as well as universal resonance. Although Müller has addressed different topics under the premise of humanitarian values, it is hard to find one collage devoted to a separate topic. Themes as loneliness, belonging, alienation, resistance, national identity and trauma can concur in one collage. Like Hannah Arendt in her coverage of the totalitarian rule, Müller is never afraid to speak her mind, and to fearlessly describe "die akute Einsamkeit des Menschen" (The acute loneliness of man) in the modern world. In The Origin of Totalitarianism, Arendt describes the desperate sense of not belonging to the world as being the most radical experience:

What makes loneliness so unbearable is the loss of one's own self which can be realized in solitude, but confirmed in its identity only by the trusting and trustworthy company of my equals. In this situation, man loses trust in himself as the partner of his thoughts and that elementary confidence in the world which is necessary to make experiences at all. Self and world, capacity for thought and experience are lost at the same time. (478) 
For Müller, as for Arendt, resistance and survival are characteristics of her collage poems. Müller favors polemical words

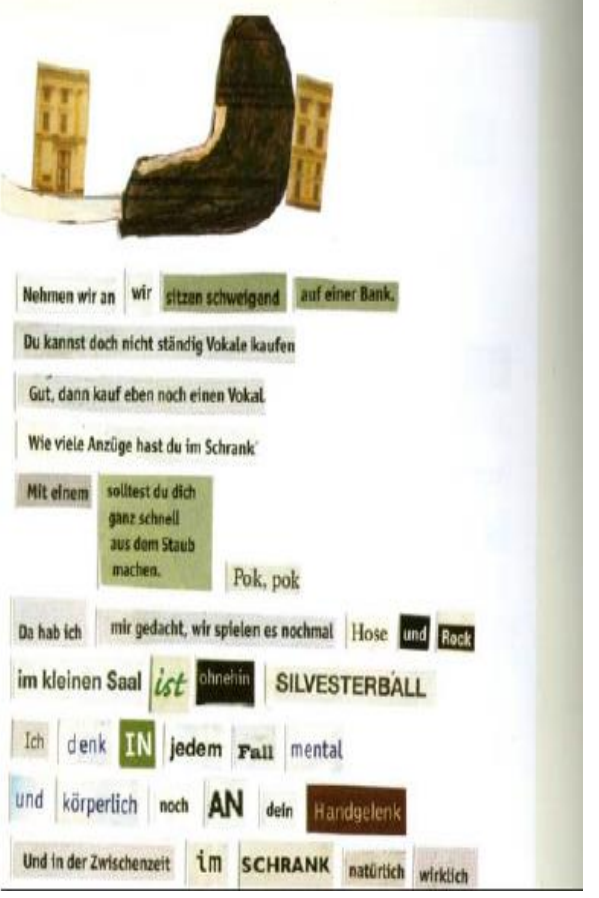
and images that challenge the reader's imagination and exceed the margins of interpretation. This why her collages demand both imagination, and thought at the same time. Themes about displacement, alienation, and fragmentation come first in Müller's collages. The collages are characterized by visual and verbal clues that signify what are left unsaid as in the following collages.

The following collage was published in 2005 in "Die blassen Herren mit den Mokkatassen" (The pale gentlemen with the mocha cups). In this collage, Müller develops the theme of alienation and brokenness in an unfamiliar way. The fragmented text and the symbolic image of the collage establish a strict separation from both the inside and the outside. On the level of the outside, there is a colored fragmented image in the upper part of the collage, while the rest includes colored poetic text with startling details. This simple image has two halves of a building, standing left and right, and in between an image of Lshape made of wood that could serve as a bench. The two halves of the building reflect fragmentation and splitting of the self into two elements (past and present/ old and new/ self and other). As for the text, the collage is condensed with visually separated words. The image here is allegorical for the reading of the emblematic text.

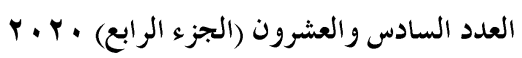

$(r V)$

مجلة كلية التربية- جامعة عين شمس 
What Can't Be Said Can Be Written: The Representation of Silence in

Herta Müller's Visual Texts

Like the image, the text is divided into two blocks separated by a square of a different color with the following sentence: "solltest $d u$ dich ganz schnell aus dem Staub machen" (you should get out of the dust very quickly). Then, the reader hears two knocks on a closeddoor "Pok, pok". Knocking on a door has nothing to do with politeness, but rather related to the controlling regime that necessitates permission for everything. This phonic sound increases the tension and functions as an external interruption. The reader cannot identify the owner of these two knocks. On the level of the inside, to begin the collage with "Nehmen wir an wir sitzen schweigend auf einer Bank" (Let's assume we're sitting on a bench in silence) means that there are two persons; a speaker and a listener. Or, the speaker here speaks to his divided psyche where the self is seen as other. What is startling in this collage is the word "schweigend" (silence) which reflects the traumatic symptoms Müller has experienced. The silence here connotes Müller's mistrust in the language being a tool of the oppressive and violent regime. The two persons in the collage are sitting next to each other without talking because they mistrust each other, or even fear the intruder who is knocking on the unseen door. The absence of sound is an effect of the absence of life. The result is that the outside of the collage leaves no traces that might endanger Müller, while the inside communicates frustration and fragmentation of the divided self.

The forced external separation between the two building blocks resembles the internal tension between the inner voice and the controlling external other. This inner voice stands for the silently resisting person, while the external one stands for the oppressive controlling regime. The argument between self and other goes in one direction; a speaking one and a listening other. The speaking voice says: "Du kannst doch nicht ständig Vokale kaufen/Gut, dann kauf eben noch einen Vokal." (You cannot keep buying vowels all

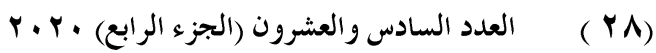

مجلة كلية التربية- جامعة عين شمس 
the time/Well, then go ahead buy another vowel). "VOKAL" (VOWEL), which is highlighted through capitalization, may stand for any significant object. However, after permitting to buy another vowel, a second decisive command comes: "you should get out very

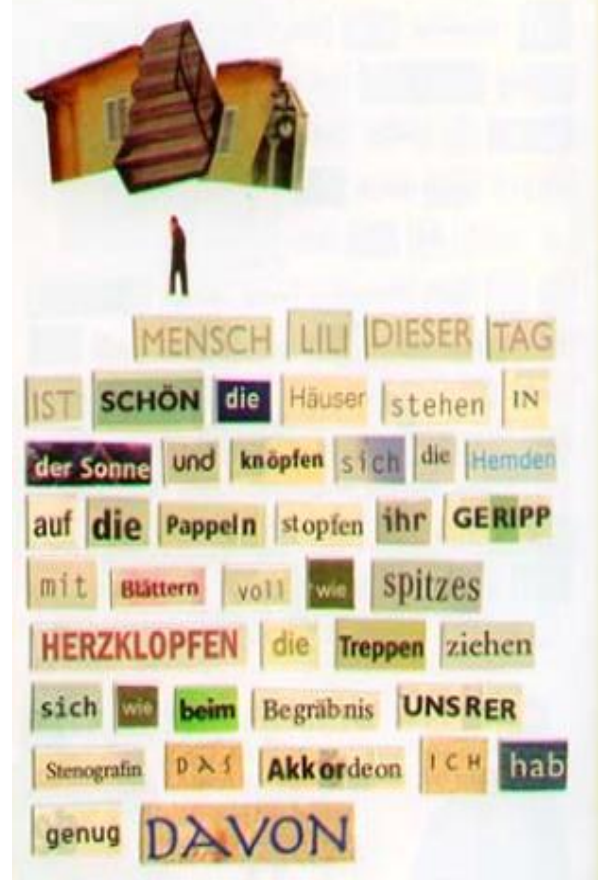

who wants to escape his psychological and emotional damage. The way he looks downward while walking in small steps connotes frustration and loss. Walking alone aggravates the impossibility to communicate with others because of fear and mistrust. Psychologically speaking, "MENSCH LILI", who stands for any oppressed individual, refuses to give up and to be crushed under the weight of the destructive force of oppression. His small steps will ensure his security and survival at the very end.

In the upper part of the collage, a house is broken into two halves and in between a stretched staircase that leads to nowhere. These stairs are like the accordion that plays in funerals that Müller has got 
enough of it: "ich hab genung DAVON". The typography of the word "DAVON" with its eye-catching color functions as decoding Müller's depressing reality. Herta Müller has also an eye-catching for signs and details, and an ability to translate them into visual terms. Müller's peculiar focus on details started early when she was herding cows in her small village. Her voice gives life to inanimate objects enabling them to speak or to keep silent. And to keep silent is to keep no human traces that might endanger you. Not only that, but the silence of language and silence of objects challenge the reader's imagination to their figurative potentials.

This collage poem belongs to the collection "Die blassen Herren mit den Mokkatassen" (The pale gentlemen with the mocha cups). This collection does not include any prefatory note or commentary which asserts the reader's entire responsibility to get the meaning from the collage alone. In the above two collages, the image and the text are connected to each other. They have the same symbolic meaning, same structure, and even tackling the same issues. Both the broken building (staat/country) and the broken house (dorf/village) in the two collages refer to the term "Heimat" (Home). The words are arranged in blocks without being connected to each other, and the two collages are teeming with words. This is because the space of freedom is measured by the number of words an individual is allowed to take. Also, these words with their incoherent semantics, pasted next to each other away from their original location, stand as if in a state of homelessness. So, Müller strives to turn humiliation into dignity by arranging ripped out words in an image shape. She says in her Nobel acceptance speech:

It seems to me that the objects don't know their material, the gestures don't know their feelings, and the words don't know the mouth that speaks them. But to be certain of our own existence, we need the objects, the gestures, and the words. After all, the more words we are allowed to take, the freer we become. If our mouth is banned, then we attempt to assert 


\section{Amal Hamza Shenishen}

ourselves through gestures, even objects. They are more difficult to interpret and take time before they arouse suspicion. They can help us turn humiliation into a type of dignity that takes time to arouse suspicion (8).

Here, and in other collages, Müller gives the inanimate objects the ability to keep silent. The broken house and the staircase are personified to express suffering and damage caused by the controlling oppressive regime. Silence can be "a metonymic vehicle to refer to complex social actions" as argues Pavlo Shopin (The Trope of Silence 20). The destruction in this collage causes a tangible change; it forces "MENSCH LILI" to move away suffering from an acute solitude. The loneliness and estrangement found in the upper two collages are identified by Hannah Arendt as central to the totalitarian rule. Yet, resistance and survival are also resonant in the collage technique. Resistance of "MENSCH LILI" is not a heroic action, but rather a worthy attempt to retain humanity in dark times.

Sometimes, destruction causes a seemingly more humiliation as in the case of Müller's mother. When she was left alone in the interrogation room, she started to clean the room with her handkerchief only to be distracted from feeling humiliated, and to create a space of dignity to herself. This same thing is found in the collages of Herta Müller where she manages to survive from her fragmented life by creating a unique fragmented structure. Müller repeatedly sketches her oppressive experiences to free herself from the unbearable solitude and the psychological pressure she has gone through. Freedom is achieved in the white space and gaps between words, in the separation between text and image, and above all in what are left unsaid.

Müller believes that "Nicht Sprache ist Heimat, sondern das was gesprochen wird" (Home is not language, but what is spoken). It seems that these two collages could be two stages of the same process. Initially, a person is sitting silently with his divided self and

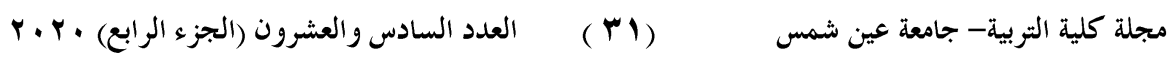


What Can't Be Said Can Be Written: The Representation of Silence in

Herta Müller's Visual Texts

he concludes that he has to get out of this messiness very quickly. Yet, when taking such a decision, the silence of speech turned into a silence of action. "MENSCH LILI", with capital letters, pinpoints the figurative meaning of silence through his failure to communicate or to take an action. Unlike the first collage, this one is void of punctuation to indicate absence (silence) of mental clarity. Furthermore, the colorful words in these two collages are ripped out from their original context and pasted in a new one as if they are in exile. It seems that the separating border between text and image

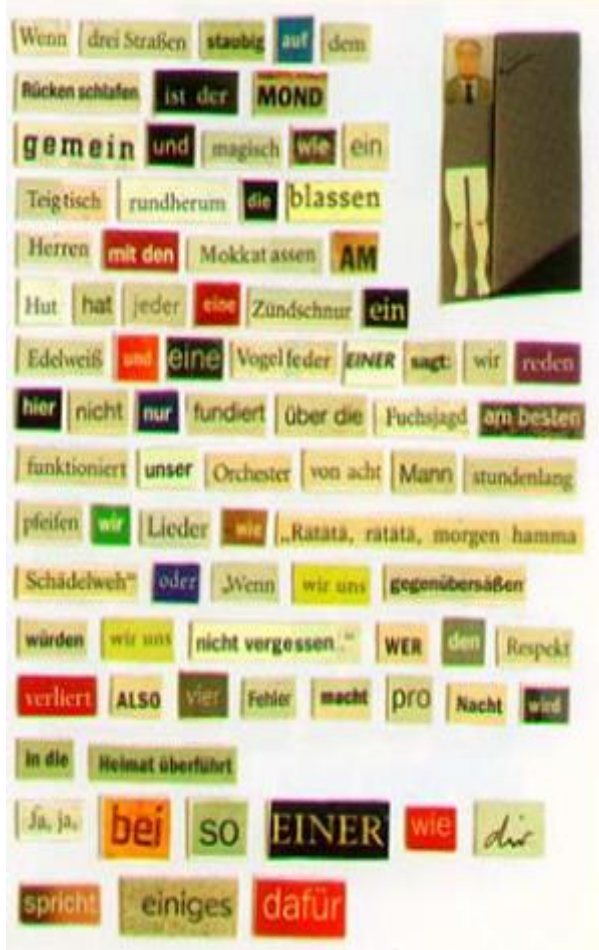
does not exist so that the reader can move freely between both.

Herta Müller's stimulus to be a writer is not to document the atrocities of the totalitarian regime, but rather to overcome the imposed silences around her. Even her mother has practiced silence after returning from the Soviet concentration camps. Müller's tactic is to express freely the truth and to keep silent at the same time. Because it is better to fight fire with fire, Müller decided to confront silence by writing, which is considered a mode of silence. So, Müller's silence works are a source domain and a target domain at the same time.

In the following collage, Müller employs different tactics. The character in the next image is marked by acute fragmentation which echoes Müller's traumatic experience, and how she suffered from a

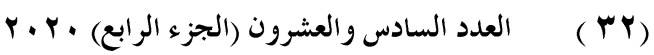

مجلة كلية التربية- جامعة عين شمس 


\section{Amal Hamza Shenishen}

minority of place within a minority of language. The focus on detail, and the analytical sharpness of image and text, which are a trademark tactic of Müller, reveals several points. First, the uncovering of fear and persecution under Ceausescu's political regime are major themes in Müller's oeuvre.

When Müller discusses the atrocities of the communist regime in Romania she carefully maps everything; shrinking and stretching events, focusing on things that seem unimportant, and ignoring important things. Müller creates her own environment to suit her cultural identity. Second, recalling these details has a therapeutic function. Every small thing is a marker of something much larger in her life. It carries parts of memories that shaped her cultural identity. Take for example the handkerchief of her mother and how it is a symbol of dignity, the accordion of the Nazi Matz, and other small things that stand for both fear and hope.

This collage begins with "Wenn drei straßen staibig auf dem rücken schlafen" (when three streets are sleeping on your back). The metaphorical meaning is unconventional in the sense that the inanimate street is given the attribute of a sleeping human being. The text makes clear that damage and danger can be caused by whatever reason. One of these reasons is not showing respect to the controlling regime. Respect here means to collaborate with the secret police, to be an informer on your friends, and to be prepared even to death. The man in this collage does not enjoy the essentials to feel at home. For him, stability, feeling safe, belonging, memory, and family are among the things that define "Heimat" (homeland). For the controlling regime, this "blasse Herren" (pale master) should be expelled out because he lacks respect "Wer den Respekt verliert". The image in the upper left corner of the collage is a photograph of a man dressed in a formal suit and a tie. The lower part of this photograph has two legs of a woman standing next to an open door made of hard steel.

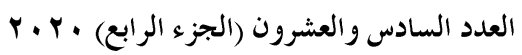

(M)

مجلة كلية التربية- جامعة عين شمس 
What Can't Be Said Can Be Written: The Representation of Silence in

Herta Müller's Visual Texts

The idea of wholeness is absent in this collage. So, this triple fragmented image is allegorical for Müller's traumatic fate. It can be interpreted as follows: the man in the upper corner is the state official who is about to expel the woman in the lower part out of her homeland. And the opened steel door stands for threats, interrogations, and even death for those who do not collaborate, and show respect to the oppressive regime. The irony of this situation lies first in not feeling at home, so it does not matter to stay or to leave. In both cases, you are a foreigner. Second, the man who is supposed to protect you from any threats is the oppressive one. Fragmentation of the image is projected back in the text. Here, words with different shapes and pleasant colors are celebrating and singing in a national ceremony where the "Orchester" (Orchestra) is playing a joyful music "rätätä". Until now everything is good. But, unexpectedly a "Zündschnur" (bomb) will turn things upside down. So, this stylish man in a tie will turn things into abyss. You cannot take anything for granted, and trust was misused by the dictatorial regime.

Although it is difficult to speak the truth, Herta Müller's abundance of reconfigured details allows a new kind of expression. Words with infinite suggestions and interpretations are liberated to memorize the dark time Müller has gone through. Müller's anger and discomfort have turned into pleasure through a twofold tactic: crushing her "Zerbrochenheit" (brokenness), and resisting the oppressive regime. 


\section{Amal Hamza Shenishen}

The next collage depicts another aspect of Müller's traumatic experience in Romania. It belongs to the collection "Vater telefoniert mit den Fliegen" (father telephones the flies) published in 2012. This collection marks a real shift from the other collections being the brightest and the lightest. This collage seems very simple and brief with a dominant black color in both image and text. This deceptive collage begins with "Kurz notiert" (briefly quoted), with a speech about a man with a name "Herr Frodi" (Mr. Frodi) with enlarged "Herr" and a very small "Frodi", and a long silence (a void and mute space) at the opening and closure of the collage. Such a

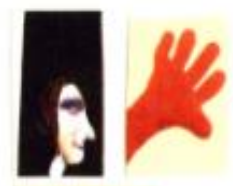

Kurz notert

Herr Frodl $\mid$ erzäht

Wein Frau in Flüsterton

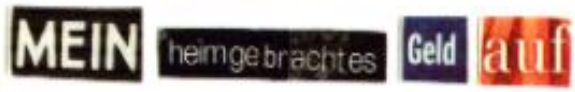

den Esstisch zählt WIRD IHR pelzgefiitterter

GAUMEN DER hässlichste

in der Welt

beginning seemingly indicates a sense of formality and respect. Yet, it reminds the reader with the official interrogations of innocent people where a list of accusations is waiting for them. Silence increases the sense of tension and uneasiness because one cannot expect what comes next. The text here is composed of a limited number of words where "Flüsterton" (whisper) and "Ort" (place) are written in black with a white background. In contrast, "meine" (my), "MEIN" (my), "heimgebrachtes" (brought home/earned), and "DER" (the) are written in white with a black background. The contrast

between black and white helps in deciphering the feelings of contempt and mistrust found in this collage. Most noticeably, the background of the collage as well as the gaps and spaces are whitecolored. Because black underlines death and oppression while white 
underlines life and survival, Müller is metaphorically asserting the possibility of resistance and survival.

So, Mr. Frodi is criticizing his wife because her mouth turns to "DER hässlichste" (the ugliest place in the world) after counting the money he earned. Such behavior is common among husbands and wives around the world. Yet, after decoding the deceptive language and the allegorical image of the collage, the meaning exceeds everyday quarrels. The controlling wife here stands for the oppressive communist regime that cannot be trusted or even confronted. The feeling of numbness between husband and wife is reflected in the image in the upper part of the collage. It consists of an intimidating smiling face of a female with a gloomy black background, a red hand, and a small table similar to those in the interrogation rooms.

Herta Müller uses concrete objects to make silence more comprehensible. The red color of the hand is not a cheerful color though red is an indicator of love. The red hand suggests spiritual injury as a direct result of political repression. Also, the pale yellow color in the image reflects the dire conditions of everyday life under the controlling regime. It "speaks for the silence imposed on the population as a consequence of censorship" as Michel Mallet asserts (50). The coloration of the collages is metaphorically employed to explore further meanings and interpretations. Michel Mallet explains:

The colours found in Müller's imagery appear, however, to be spiritually traumatized, a condition that reflects her own traumatic experience. As she points out herself in her essay "Der König," her imagery is composed of "[. . .] Farben, die nicht mehr wanderten" (König 55), suggesting here that her colours are injured, faded winged creatures in Benjamin's sense that reflect the desperate life conditions of her protagonists, who remain destitute of freedom and of hope 


\section{Amal Hamza Shenishen}

under the constraints of regressive traditions and totalitarian dictatorship (40).

The idea of absence of freedom is not confined to the content of the collage with words that conceptualize repression and harassment. The form of the collage where blocked and incongruent words are listed beside each other inside a suffocating frame from which they are unable to free themselves is an added obstacle that triggers both physical and psychological confinement. The blocks of words lead to an interrupted reading - it interrupts the natural flow that we normally use to read a line. We are insecure about the rhyme because most words are not connected through the same fonts and sizes. Only a rereading brings us closer to the natural rhythm. Their disparate origins form a beautiful "whole" that does not conceal its fragmented sources (Moyrer 203).

Herta Müller has early experienced numbness and alienation in her small village in Romania. Even after winning the Nobel Prize, the impact of her writings is partial and delayed. Because her life lacks coherence, some of her collages too are incomprehensible similar to her life. Images like a man sleeping in a watermelon, or a headless human body with a fox head and a tail show fragmentation, and disruption. Yet, these ungraspable images, with body parts, do have allusions to the secret police and the physical effects of repression. To cut parts of a human body into minute pieces with a sharp scissor signifies Müller's focus on detail, but also mount the effect of trauma. Like her images, Müller has long experienced what Hannah Arendt identifies as the essence of totalitarianism; loneliness and atomization. Now, why would someone do something so subservient? How could such collages be a tool of resistance and survival? The answer is, to embody the dissociation and fragmentation that result from trauma is better than to describe them. Cutting and pasting your past memories gives unity and wholeness to the individual. 
What Can't Be Said Can Be Written: The Representation of Silence in Herta Müller's Visual Texts
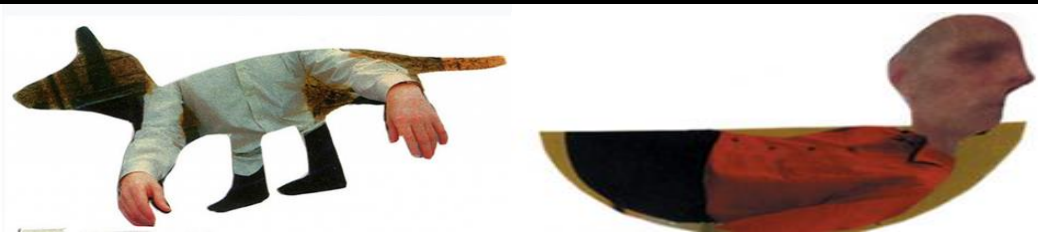

Müller is trying to produce a work that explores natality (newness) to illuminate her path in the dark times. Her collages, simple as they are, mark a move away from partiality to impartiality. In reading a collage, one is free to jump between words, to read vertically or horizontally, and to connect words with the image. The colors, fonts, and typography are whispering to the reader with different interpretations. The meaning of things is linked to their spatial environment, and part of their hidden meanings is granted by their location. Eye-catching words can be read in isolation from others and can be decoded differently. Words with visual typographical features stand as clues in each

seloiger Ball des Auges

STILLE Kugelpupille ich glaube DIE FARBE DER KOHLE Weiß

Wem ICA FEHLE |MIT EINEM gelben Hahn im ARM sagte ein mann am Bahndamm Richtung gibt's $\| \mathbb{N} \mid$ allen $\mid$ Fallen WO Sie wollen aber |Rückkehr WÄRE EINE SO BLAUE Affäre wil DER BLINDE Dienst

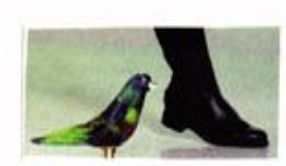

der Winde collage. Words as "Bahndamm" (Dam) in green color, "BLINDE" (blind) in black color can be associated with the two components of the image to interpret the collage. The word in green unmuted color in the middle of the collage connotes life, protection, and survival. While the word in black muted color at the end of the collage connotes death, and oppression.

Unsurprisingly, the image at the bottom of the collage has two elements; a green bird to connote life and freedom, and a black shoe that connotes

r.r. . العدد السادس والعشرون (الجزء الرابع) $(\Gamma \wedge)$ مجلة كلية التربية- جامعة عين شمس 
violence and cruelty. The bird and dam which are symbols of life are defeated by blindness and oppression.

The ability to communicate with others or even with your self is the first and foremost concern of Herta Müller to overcome physical and psychological censorship. This includes silence as a way of communication. Although the incongruent words in all collages are arranged in blocks to interrupt the reading and prevent communication, there exists another kind of internal communication. Müller personifies inanimate objects to make them able to speak and keep silent. This kind of inner communication is apparent in this collage where two travelers at the train station are communicating with each other. What is peculiar about this collage is the relatively small image at the bottom where a colored bird is standing on the ground next to a black shoe in the foot of a man. One traveler is saying to the other: "Richtung gibt's in allen Fällen wo Sie wollen aber Rückkehr wäre eine so blaue Affäre" (direction existed by all means to where you'd like to be but returns were such a blue affair like the blind shifts / of the winds). So, the inability to return to homeland once it has been left aggravates the sense of "Unheimischsein" (un-homeyness). Similar to the bird standing on the ground is very risky and dangerous because it is not supposed to be here.

According to Lyn Marven, fragmentation is one of the tactics Müller regularly employs in her collages so as to describe her suffering and social subjugation metaphorically. Fragmentation, as a symptom of destruction and subsequently a symptom of trauma, has been described as the mark of Müller's aesthetic style. Trauma is visible in the content and form of Müller's collages in order to achieve the utmost effect. Marven says: "Trauma becomes visible in the texts' content, and also in the aesthetic of fragmentation which structures their linguistic and narrative syntax" (397). Müller uses fragmented language for two reasons; first to portray her suffering, and second to beseech sympathy from her readers. Müller does not

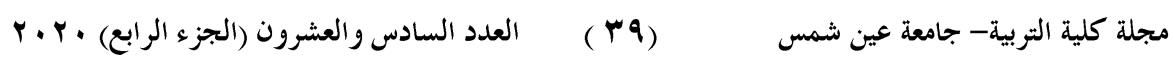


attempt to explain her suffering or her trauma because trauma is inexplicable. Instead, the reader can get from the individual words, from the gaps, and from the distinction between text and image the anticipated meaning. Trauma has become the framework of Müller's collages.

The mapping of the following collage from the collection "Im Haarknoten wohnt eine Dame" (A lady lives in a hair knot) is a little bit different from collages of other collections. Image and text are given a relatively equal space, and black and white are the dominant colors here. As a matter of fact, to mute colors in this collage is to bestow them the ability to keep silent. The incongruous form of the image in this collage expresses both the physical threat and the

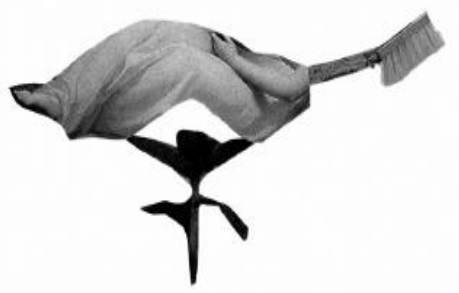
psychological repression. The fragmented image here is reduced into two legs, one hand, and a toothbrush instead of a head. This fragmented body is lying asleep on something that resembles a tree. Müller's choice of this image with the absence of

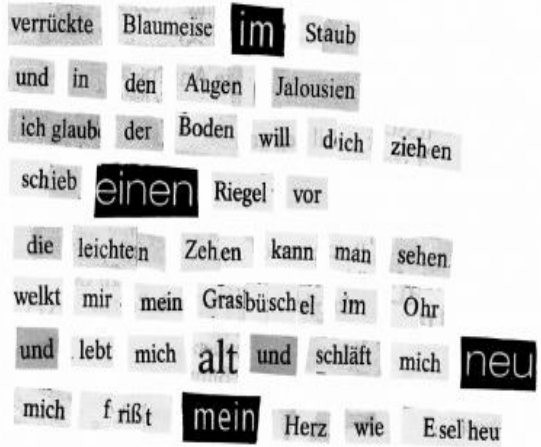
the head and the sleeping and motionless fragmented body reveals multiple meanings. First, the toothbrush is one of the provocative words used in the collages of Herta Müller. Words as a suitcase, toothbrush, packing, a handkerchief, a staircase, and others are signs of always being prepared either to be arrested or to escape from the secret police. This headless figure is no more a human being simply because he is deprived of freedom of speech. Second, to be hanged motionless on a tree without having 
a home to return is a metonymy of the inhospitable environment he/she is living in. She escaped from communism only to be faced with fascism.

One final example of speaking through silence is "Gürtel und Hals" (belt and neck) collage. It belongs to the collection "Im Haarknoten wohnt eine Dame" (A lady lives in a hair knot), published in 2000. Müller seeks to present to her readers the everyday life of an ordinary human being through extraordinary mode. The muted colors (black/grey) of this collage should be
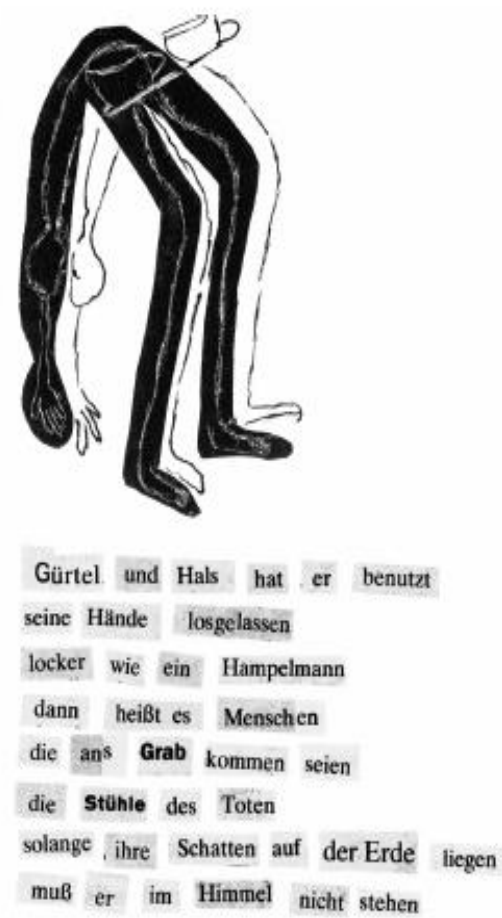
interpreted as a reminder of the long endured oppression, and also of the dire conditions of everyday life in such a socialist regime. Müller combines the muted colors with the symbolic figure to indicate the oppressive mechanism of the Romanian dictatorship. The interplay between image and text is highly emblematic. She engages the reader's imagination to encourage different interpretations. "Gürtel und Hals" collage has a different design where image and text have given equal space. Unlike collages in other collections, this one is not teeming with words.

Two elements characterize this collage: a picture drawn by pencil where a human being is bending backward and downward until he touches the ground, and the text in black color. Splitting or doubling of the self is seen in the shadow or the reflection of the figure.

Because Müller's experience cannot be expressed by words only, the image here is very appropriate to the text. The text is a reflection 
of the image in the same way the human being in the collage has been reflected in white and black colors. The contrast between black and white reflects the contrast between day and night, and between life and death. The attention of the reader is caught in certain words. First, the collage begins with "Gürtel und Hals" (belt and neck) which could be tools of torture or even tools of committing suicide. Second, "Grab" (dig) and "stühle" (chairs) which are written in bold to connote death. The neck and head of the person are bent backward and downward which denotes uneasiness. This is what totalitarianism does to individuals. They are living under the threat of death, in desperate and gloomy conditions, and they are striving for freedom as appears in the white shadow of the figure.

In her Nobel acceptance speech, Müller speaks of how she looked after the cows, and the sound of words looked after her. She describes her feeling: "Every word in your face/ Knows something of the vicious circle/ But doesn't say it" (8). From this moment on, Müller learned how to listen to the whispering sound of objects, animals, and plants around her. And above all, she learned how to speak in instead of speaking out. For Herta Müller, writing is a mode of silence, and for her readers, reading is also a mode of silence. In writing, which is regarded as a defensive strategy, Müller is free to encode her traumatic experience and to express what she has experienced and perceived through the silence of language and silence of objects. And in reading, the reader is free to decode the metaphorical language that describes the terrors of dictatorships. This reciprocal relationship between the author and the reader resembles the process of encoding and decoding of information. Because of the inexpressibility of silence in the normal and direct way, it can be conveyed only through metaphoric language. So, Müller continues with two things in her collages: conceptualized metaphor and a fragmented muted language with a focus on detail. Metaphor is not mere ornamentations, but rather an indispensable aspect in understanding the collages:

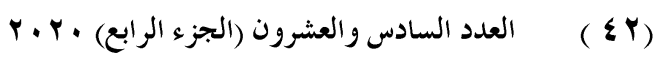

مجلة كلية التربية- جامعة عين شمس 


\section{Amal Hamza Shenishen}

Poetic metaphor, far from being ornamentation, deals with central and indispensable aspects of our conceptual systems. Through the masterful use of metaphorical processes on which our conceptual systems are based, poets address the most vital issues in our lives and help us illuminate those issues, through the extension, composition, and criticism of the basic metaphoric tools through which we comprehend much of reality. (Lakoff 215)

Thus, silence for Herta Müller has become the cause and effect; the source domain and the target domain. In other words, Müller has suffered from the imposed silence, and at the same time, she uses silence to avoid persecution, harsh punishment, and death. For this reason, silence has become a multisensory aspect able to illuminate the harsh reality of Müller and other victims.

Herta Müller has experienced multiple dichotomies starting from being an ethnic minority in Romania, then suffering from the consequences of the Third Reich after the end of WWII, and finally from feeling different in the German society. The split of her life between Eastern Romania and West Germany, and of being an outsider and an insider at the same time, have resulted in what can be named as the disintegration of the self. The disruption and annoyance of this psychological state resulted in nuisances of the texts and images of her collages. Collaging has become a creative space; a white sheet through which Müller deals with her reality in a highly poetic way.

Collage is exquisitely a poetic and aesthetic art where Müller manages to alleviate the burden of oppression imposed upon her. While the gears of Ceauşescu's totalitarian machinery are fear, humiliation, fragmentation, interrogations, interceptions, and oppressions, the gears of Müller's collages are silence and metaphoric language. Her collages are characterized by startling typography where words with different fonts and sizes have different semantic connotations. Coloration has a decisive role where muted colors like black and grey connote the absence of life,

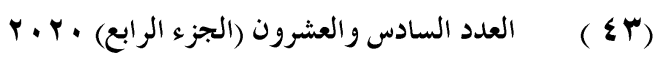

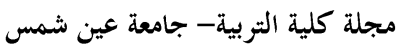


while unmuted and pleasant colors help in relieving the weight of subjugation imposed upon the victims by this social order. Punctuation and rhyme are other aspects of Müller's literary style. Lack of punctuation in some collages reflects a lack of clarity and creates a distorted meaning especially in a text composed of words rather than comprehensive sentences. Regarding rhyme that appears in some collages about death, murder, and suicide, it represents the repeated fear and terror inside the interrogation rooms, and how it is projected back in the fragmented texts. The ambiguity of Müller's collages, the fragmented language, and the inexplicable images, are increasingly linked to the unassimilated trauma. What mostly marks Müller's aesthetic style is focusing on detail. Müller herself lives in detail; her fragmented life resembles the fragmented characters in her collages. She adopts detail as an art of resistance

One more tactic of Müller's collages is the broken beginning and ending that increases ambiguity. Because words and images are ripped out from different sources, each element bears a separate meaning depending on its context. It remains that Müller managed to say in silence what she could not write explicitly.

\section{CONCLUSION}

Hera Müller has long endured persecution, interrogation, torture, and oppression until she resolved to resist and to speak the truth through a de-familiar language. Contrary to the principle of expressibility that whatever can be meant can be said, Müller believes that language is not the only means of expressibility. She has developed a sophisticated way of communication by whispering silently through gaps and fragmented spaces. Silence for Müller is not a failure of communication, but rather an alternative language. Silence serves as a way of survival through protesting the dictatorial power. In Müller's collages, the meaning of silence is not delineated but left to the reader's interpretation. 


\section{Amal Hamza Shenishen}

Because silence is anything but nothing, all the reader needs are to listen wisely to the whispering of words and to see the word as an image and the image as a word. Both the content and the form of Müller's collages are focusing on the reader's ability to extract the figurative meaning of the salient and at the same time cautious language. Her critique of dictatorships and oppression through her employment of manipulative language and fragmented pieces leaves no traces so as not to endanger herself. Müller moves freely through gaps and blank spots where she can find trust and confidence. This is because her collages are like a baffling puzzle where deception and non- conformity are its outer appearance. Yet, penetrating deeply underneath words, images, colors, blank spots, and fragmented pieces one can find a complete whole.

Hera Müller's collages are conceptualizing metaphors about home, exile, immigration and above all her traumatic experiences. Through these metaphors, the reader is invited to decode the sonority of her magical collages hidden underneath signs of the visual and the aesthetic traits. Images in Müller's collages share one commonality albeit she gives her reader freedom of interpretation.

Müller's mapping of her collages depends on randomness rather than selection, typography, manipulation of language, coloration, and the figurative quality of what are left unsaid. On the level of the content, the text with variable fonts, sizes, and colors is seen as a body where the part is seen as a whole and the whole is seen as a part. Müller, like a gymnastic or even a dancer, is flexibly bending her words and is moving between past and present, between Romania and Germany, and between fear and hope. On the level of form, collages are strongly visual where separation and brokenness are the dominant features. The result is a true combination between content and form and between text and image where details are charged with different interpretations, and aesthetic functions. 
What Can't Be Said Can Be Written: The Representation of Silence in

Herta Müller's Visual Texts

Like Hannah Arendt, Müller's collages are more about asking questions than giving answers. The collages call for what Arendt defines as vigilant partiality. So, after whispering to herself that she is a broken character, Herta Müller turned this brokenness into a silent language to restore her fragmented identity. Her collages have become a form of resistance and survival.

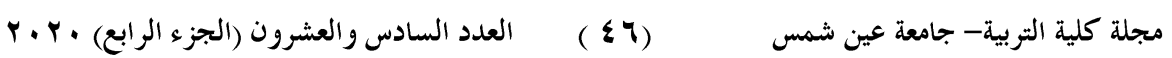




\section{WORKS CITED}

Aschheim, Steven E. "Nazism, Culture and The Origins of Totalitarianism: Hannah Arendt and The Discourse of Evil." New German Critique, no. 70, 1997, pp. 117-139. JSTOR, www.jstor.org/stable/488501. Accessed 5 Dec. 2020

Brandt, Bettina, and Valentina Glajar, editors. Herta Müller: Politics and Aesthetics. University of Nebraska Press, 2013. JSTOR, www.jstor.org/stable/j.ctt1ddr8pv. Accessed 7 Sept. 2020.

Hockney, D., \& Joyce, P. Hockney on 'Art', London: Little, Brown \& Company, 1999.

Ihab Hassan, The dismemberment of Orpheus. Toward a Postmodern Literature, New York, Oxford University press, 1971.

Jałowik, Delfina. “"Each Word Aquires Each Own Personality': Herta Müller Talking about Her Collages." Herta Müller: Where One Cannot Speak: Word as Image, Image as Word, MOCAK, Kraków 2019 (2019): 110-124.

Kohl, Katrin. "Beyond Realism: Herta Müller's Poetics", in Herta Müller, ed. by Brigid Haines and Lyn Marven (Oxford: Oxford University Press, 2013), pp. 16-31.

Krauss, Rosalind. The Originality of the Avant-Garde and Other Modernist Myths Cambridge: MIT Press, 1991.

Lacan, Jacques. The Four Fundamental Concepts of Psycho-Analysis, ed. by Jacques-Alain Miller. London: The Hogarth Press and the Institute of Psycho-Analysis, 1977.

Lakoff, George, and Mark Turner. More than Cool Reason: A Guide to Poetic Metaphor. Chicago: U of Chicago P, 1989. .

Marven, Lyn. "So fremd war das Gebilde": The Intersection between Visual and Verbal in Herta Müller's Prose and Collages." Herta Müller, edited by Brigid Haines and Lyn Marven, Oxford UP, 2013, pp. $135-52$.

. "In Allem Ist Der Riss': Trauma, Fragmentation, and the Body in Herta Müller's Prose and Collages." The Modern Language Review, vol. 100, no. 2, 2005, pp. 396-411.JSTOR, www.jstor.org/stable/3737605. Accessed 17 April. 2020.

Moyrer, Monika A. Unheimisch in Deutschland: Fragmentation, Collage, and Performative Aesthetics in Herta Mueller's Writings, University of Minnesota, Ann Arbor, 2007. ProQuest, Web. 22 Mar. 2020.

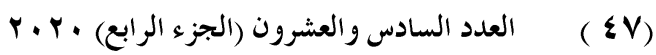

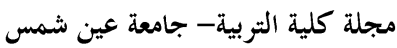


What Can't Be Said Can Be Written: The Representation of Silence in

Herta Müller's Visual Texts

. "In Transit: Transnational Trajectories and Mobility in Herta Müller's Recent Writings." Herta Müller: Politics and Aesthetics, edited by Bettina Brandt and Valentina Glajar, University of Nebraska Press, Lincoln; London, 2013, pp. 184-206. JSTOR, www.jstor.org/stable/j.ctt1ddr8pv.15. Accessed 18 Aug. 2020

Müller, Herta. Die blassen Herren mit den Mokkatassen. Carl Hanser

Verlag, Munich, 2005.

. Este sau nu este Ion. Iași, Polirom, 2005.

. Este sau nu este Ion. Bucuresti: Editura Polirom, 2005.

. Father's on the Phone with the Flies: A Selection, Seagull

Books, Munich, 2018.

. Every word knows something of a vicious circle. Pontefract:

Route. 2010.

Hamburg, 2000.

2012

. The Hunger Angel. Trans. Philip Boehm. Metropolitan Books,

Shopin, Pavlo. "The Trope of Silence in the Work of Herta Müller."

Oxford German Studies 47.2 (2018): 241-254. Web. Oxford German Studies, 47. 2, 241-254, June 2018

. "Metaphorical Conceptualization of Injurious and Injured

Language in Herta Müller." The Modern Language Review, vol. 111, no. $4, \quad 2016, \quad$ pp. 1068-1084. JSTOR, www.jstor.org/stable/10.5699/modelangrevi.111.4.1068. Accessed 18 May. 2020.

. From Injury to Silence: Metaphors for Language in the Work of

Herta Muller, 2017.

(Doctoral thesis). https://doi.org/10.17863/CAM.13425

Siegel, Nica. "The Roots of Crisis: Interrupting Arendt's Radical Critique." Theoria: A Journal of Social and Political Theory, vol. 62, no. 144, 2015, pp. 60-79., www.jstor.org/stable/24719945. Accessed 28 Nov. 2020.

Verovšek, Peter J. "Unexpected Support for European Integration: Memory, Rupture, and Totalitarianism in Arendt's Political Theory." The Review of Politics, vol. 76, no. 3, 2014, pp. 389-413., www.jstor.org/stable/43670988. Accessed 28 Nov. 2020.

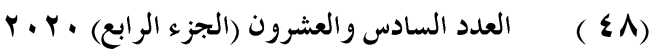

مجلة كلية التربية- جامعة عين شمس 


\section{Amal Hamza Shenishen}

Villa, Dana. "Hannah Arendt, 1906-1975." The Review of Politics, vol. 71, no. 1, 2009, pp. 20-36. JSTOR, www.jstor.org/stable/25655783. Accessed 28 Nov. 2020.

Winham, Ilya. 'Rereading Hannah Arendt's 'What Is Freedom?': Freedom as a Phenomenon of Political Virtuosity." Theoria: A Journal of Social and Political Theory, vol. 59, no. 131, 2012, pp. 84-106.JSTOR, www.jstor.org/stable/42705243. Accessed 28 Nov. 2020

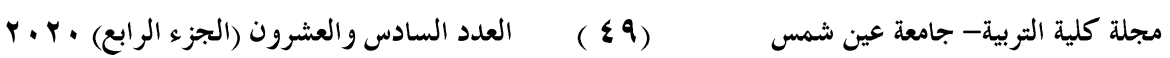

